\title{
ENTRE SUBJETIVO E CITADINO: "ANOITECER", DE CARLOS DRUMMOND DE ANDRADE
}

BETWEEN SUBJECTIVE AND CITY: A READING PROPOSAL FOR "ANOITECER", BY CARLOS DRUMMOND DE ANDRADE

Rodrigo Valverde Denubila*

RESUMO: Este estudo consiste em uma leitura crítica de "Anoitecer", poema de Carlos Drummond de Andrade, publicado em $A$ rosa do povo. Objetiva-se evidenciar como a organização formal reflete o conteúdo. Sublinha-se, pois, como os aspectos expressivos formais estão comprometidos com os aspectos expressivos existenciais. No itinerário de leitura proposto, evidenciam-se questóes proprias à modernidade e ao espaço citadino. Porém, essas são transcendidas quando aparecem outras ligadas à temporalidade do ser. Isso faz com que se identifique dicotômica articuliça semântica entre subjetivo e citado, entre facticidade existencial e eternidade.

PALAVRAS-CHAVE: Carlos Drummond de Andrade: "Anoitecer"; morte; metrópole.
* rodrigo.denubila@gmail.com

Doutor em Estudos Literários pela UNESP/Araraquara. Realizou pesquisa de pós-doutoramento na mesma instituição estudando as relações entre modernidade e pós-modernidade, modernismo e pós-

ABSTRACT: This study consists of a critical reading of "Dusk", poem by Carlos Drummond de Andrade, published in The Rose of the People. The objective is to evidence how the formal organization reflects the content. It is therefore underlined how the formal expressive aspects are committed to the existential ex pressive aspects. In the proposed reading itinerary, questions specific to modernity and city space are evidenced. However these are transcended when others are associated with the temporality of being.

KEYWORDS: Carlos Drummond de Andrade; "Anoitecer"; death city. 
"Anoitecer"

\section{A Dolores}

1 É a hora em que o sino toca 2 mas aqui não há sinos;

3 há somente buzinas,

4 sirenes roucas, apitos

5 aflitos, pungentes, trágicos,

6 uivando escuro segredo;

7 desta hora tenho medo.

8 É a hora em que o pássaro volta,

9 mas de há muito não há pássaros;

10 só multidões compactas

11 escorrendo exaustas

12 como espesso óleo

13 que impregna o lajedo;

14 desta hora tenho medo.

15 É a hora do descanso, 16 mas o descanso vem tarde,

17 o corpo não pede sono,

18 depois de tanto rodar

19 pede paz - morte - mergulho
20 no poço mais ermo e quedo;

21 desta hora tenho medo.

21 Hora de delicadeza,

22 gasalho, sombra, silêncio.

23 Haverá disso no mundo?

24 É antes a hora dos corvos,

25 bicando em mim, meu passado,

26 meu futuro, meu degredo;

27 desta hora, sim, tenho medo.

(ANDRADE, 2002, p. 122 e 123)

Quatro estrofes formadas por sete versos constituem estruturalmente "Anoitecer", de Carlos Drummond de Andrade, publicado em A Rosa do Povo, de 1945 Em primeira leitura, o eu lírico descreve o fim do dia de uma cidade grande, como indicado no título. Todavia, reduzir a peça lírica a isso seria simplista, pois, em segunda leitura, o caráter existencial ganha corpo, qua ndo questiona mentos nascem pela dualidade entre espaço urbano/metrópole e espaço rural/vila campestre.

O movimento a mbivalente arma-se nas duas primeiras estrofes e chega à confissão lírica na quarta e última Realiza-se trajeto em que inicialmente se apresenta a alternância entre espaços, seguida da argumentação que conduz 
à conclusão final, presente no último verso. Este, marcado por força expressiva ampliada, quando o estribilho - "desta hora tenho medo" - ganha o advérbio "sim", escrito entre vírgulas, o que cria efeito de realce de informação: "desta hora, sim, tenho medo" (ANDRADE, 2002, p. 123).

Os versos de "Anoitecer" são livres e brancos. Todavia, há sonoridade, o que gera o ritmo, o qual, como frisado por Antonio Candido (2006), no Estudo analítico do poema, representa importante recurso expressivo para a tessitura do argumento poético. Em 1930: a crítica e o Modernismo, João Luiz Lafetá (2000) acentua a importância do ritmo no verso modernista para a construção de novas tonalidades estéticas, aspecto esse ta mbém destacado por Hélcio Martins (1968) e por Antonio Candido (2005), em estudos que se debruçam na produção drummondiana.Feito esse breve percurso inicial, iniciam-se os passos desta caminhada exegética.

\section{PRIMEIROS PASSOS}

Começa-se este percurso interpretativo refletindo sobre o número sete e o quatro, a mbos presentes na estrutura de "Anoitecer", composto por quatro estrofes com sete versos. O sete representa a conclusão de um ciclo e a renovação (CHEVALIER \& GHEERBRANT, 2009). Como apresentado, o eu lírico descreve o fim do dia de uma cidade grande, logo, o fechamento de pequeno ciclo temporal em escala acumula tiva: segundos formam minutos; estes, horas; estas, dias. Dias se tornam anos, anos se tornam décadas, décadas se tornam séculos.

Nesse movimento, a história coletiva e a individual se desenham e formam ciclos. Ciclos semelhantemente qualificam a factualidade dos seres. Nascimento e morte denota $m$ o início e o fim de etapa maior chamada existência. Como na divisão temporal, diversos círculos experiências compõem o círculo vida. Quando aqueles começam a se fecharem antes do fim deste, receios podem surgir frente às incertezas do futuro, pois mudanças qualificam o existir. Isso está em concordância com outro aspecto simbólico desse número, pois "o sete encerra [..] uma ansiedade pelo fato de que indica a passagem do conhecido ao desconhecido: um ciclo concluído, qual será o próximo?" (CHEVALIER GHEERBRANT, 2009, p. 828). Existe, portanto, na construção estrutural de "Anoitecer" índices de significação importantes, que evidenciam o caráter interrogativo do poema, mas este ta mbém dialoga com seu tempo.

Em "Palestra sobre lírica e sociedade", Theodor Adorno (2003) argumenta que nenhum poema é individual, visto que todos fazem parte de uma cultura e de contextos sócio-históricos. Desse modo, cabe retomar o momento qualificador da escrita dos poemas de A Rosa do Povo. Os 55 
poemas que compõem a obra foram escritos entre 1943 e 1945. No Brasil, havia os tempos do Estado Novo getulista, com seu caráter centralizador e autoritário. No mundo, os anos finais da Segunda Guerra Mundial, a qual desolou a Europa e expôs a barbárie, haja vista que a engenhosidade humana capaz de produzir o avião gerou ta mbém os campos de concentração, marcados pela lógica organizada, programada e mecânica de extermínio.Nesse contexto, segundo Zygmunt Bauman (1998), em Modernidade e holocausto, a modernidade e o homem entram em crise após a Segunda Grande Guerra. Se a modernidade social, que visava à criação de um mundo melhor, produziu a guerra, o extermínio, a massificação do homem, então, o que esperar de bom depois dela? Esse dado aparece em "Anoitecer" e em maior grau, na poesia drummoniana, bem como nos estudos críticos de Carlos Drummond de Andrade:

Não é fácil decidir se nossa época se caracteriza pelo excesso ou pela míngua de crença. Enquanto o século XVIII ficou marcado pelo racionalismo filosófico e revolucionário, e o século XIX pelo cientificismo e a ideia socialista, o período em que vivemos não logrou ainda definir-se como um tempo ateu, místico, idealista, materialista, hedonista, surrealista, infantil ou bárbaro. Engajado em todos os rumos, nosso tempo não se entregou a nenhum deles, como os amantes se entrega m no ato amoroso. (ANDRADE, 2003, p. 259)
Vivendo, pensando e escrevendo em momento intenso, plural e conflituoso, o poeta mineiro se entende como cantor do tempo presente, como lembram os versos de "Mãos dadas", publicado em Sentimento do Mundo, de 1940. Em vista disso, é luminosa esta ponderação de Carlos Drummond de Andrade (2011, p. 59), retirada do ensaio "Pessimismo de Abgar Renault": "Não é a subordinação ao tema de circunstâncias, mas o reconhecimento da verdade de que o poeta só pode se alimentar do tempo, e que o tempo de hoje não é inferior a qualquer outro nem deve ficar de conserva, até transformar-se em passado, para atrair a prospecção lírica”.

Em suas argumentações críticas, o poeta mineira frisa a necessidade de se compreender o mundo presente em que vive, logo, não almeja construir paraísos líricos amenos, já que o retrato na parede, lembrando outro tempo, dói, como afirma o eu poético de "Confidência do Itabirano". Apreender o contemporâneo não é tarefa fácil, mas nessa empreitada alguns autores captam as tendências de um tempo e constroem verdadeiros testemunhos do seu tempo, como aconteceu com Carlos Drummond de Andrade em relação ao século XX.

Seria muito bom que os romancistas fossem apenas romancistas, os poetas puramente poetas, mas a verdade é que eles
EM TESE
BELO HORIZONTE
v. 25
N. 3
SET.-DEZ. 2019
DENUBILA. Entre subjetivo e citadino: "Anoitecer", de Carlos Drummond [...] P. 44-63 
se comunicam, através de inumeráveis condutos, com as correntes morais, políticas e filosóficas que banham o mundo, e que sem essa comunicação não existiria mesmo a matéria que produzem, isto é, a litera tura. (ANDRADE, 2011, p. 104)

Silviano Santiago (2002) frisa a importância do testemunho poético drummondiano para o século XX à medida que o poeta itabirano capta a vida "em sua forma irredutível/ já sem orna to ou comentá rio melódico/ vida a que aspiramos como paz no cansaço/ (não a morte)" (ANDRADE, 2002, p 144). Olhando o seu presente, o autor via-se diante de um "mundo caduco" (ANDRADE, 2002, p. 80). O adjetivo abre questionamentos: envelhecido por quê? Em eminência de cair por quê? Que perdeu a lucidez por quê?

Após a queda dos projetos utópicos de anulação das mazelas humanas oferecidos pela razão iluminista, o eu lírico drummondiano passa a sentir medo - afeto recorrente na lírica desse período - do que vê, à medida que canta o tempo presente. Sente a necessidade de se perguntar o que o fim desse ciclo existencial da modernidade, "o tempo de homens partidos" (ANDRADE, 2002, p. 125) e o início de outro pode trazer. O momento que se principia após o conflito mundial pode ser "mais noite que a noite" (ANDRADE 2002, p. 67)? Será que o mundo não estava devolvendo algo ruim aos homens devido a sua postura petulante?
Observar o mundo caduco e contemporâneo do poeta significa tentar lirica mente responder essas inquirições, mas semelhantemente se deparar com a escuridão das respostas. Complementar a esse entendimento, pode-se evocar estas palavras de Alcides Villaça (2006, p. 75), em Passos de Drummond: "No horizonte dos melhores poemas de A Rosa do Povo não há certezas políticas, mas alvos custosos da esperança de um atirador meio sem pontaria e nada triunfal, que avalia a dificuldade da mira e o alcance do gesto tímido e personalista".

Não é fortuito, pois, nesse cenário maior, que a hora que o eu lírico de "Anoitecer" sente medo é a do início da noite, quando a muda nça de iluminação embaça e dificulta o olhar, logo, a mira desse "atirador sem pontaria". Em dois campos semânticos, no poema, há a noite do mundo moderno, após 1945, e a noite do homem trabalhador, que volta ao lar depois de mais um dia que se finda.

Conforme sublinha Antonio Candido (2011, p. 82), em "Inquietudes na poesia de Drummond", o trabalhador equivale a importante temática: "A ideia do escravo (de homem privado dos meios de humanizar-se) combina-se com a ideia de rua, praça, cidade (isto é, o espaço social em que se define a sua alienação) e a mbas convergem na ideia de "mundo caduco"'. Mundo a noitecendo, caduco e formado por mercadorias que espreitam os indivíduos em sua volta 
diária, como descrito em "A flor e a náusea". Tal ideia se coaduna ao valor simbólico do quatro, o mais totalizador dos números, aquele que representa de forma ma is sensível a realidade do mundo material, de acordo com Chevalier e Gheerbrant (2009). Qual a realidade do mundo materia moderno? A emergência de mercadorias e da burguesia bem como a transformação das cidades. Tais itens atravessam a poesia drummondiana. Nota-se, pois, como aspectos ligados ao século XX estão presentes em "Anoitecer".

\section{SEGUNDOS PASSOS}

Neste segundo momento, focaliza-se cada uma das estrofes mais apuradamente. Eis a primeira:

1 É a hora em que o sino toca,

2 mas aqui não há sinos;

3 há somente buzinas,

4 sirenes roucas, apitos

5 aflitos, pungentes, trágicos,

6 uivando escuro segredo;

7 desta hora tenho medo.

O poema inicia-se com um verbo de ligação cuja função gra matical consiste em qualificar um sujeito, pois liga predicativos (qualificadores) a um substantivo (nome). Ta construção frasal descreve estado permanente, transitório, contínuo ou aparente. $\mathrm{Na}$ forma nominal, que dá título ao poema, o verbo a noitecer pode ser substantivado por artigo definido: "o anoitecer". O verbo equivale, portanto, ao sujeito oculto da oração inicial, lida assim: "O a noitecer é a hora em que o sino toca”.

Do mesmo modo como se passa com o sujeito do sintagma nominal, está oculta a subjetividade do eu lírico, que se apresenta timidamente neste primeiro momento. De forma a mpla, Antonio Candido (2011, p. 71) ressalta o aspecto discreto do eu poético drummondia no, na medida em que o "eu é uma espécie de pecado poético inevitável, em que precisa incorrer para criar, mas que o horroriza à medida que o a trai”. No momento sócio-histórico da produção dos poemas de $A$ rosa do povo, focar no eu simboliza uma espécie de traição da necessidade do nós.

Além de compreender como um verbo se torna sujeito oculto e recebe predicativos, cumpre pensar como qualificadores são reformulados depois de postos, de apresentados. Após a construção do sintagma nominal, a conjunção adversa tiva "mas" abre o segundo verso do poema e modaliza os atributos descritos. O valor semântico de oposição esmaga a qualidade apresentada no primeiro verso para o anoitecer. Lê-se este sentido: "O anoitecer é a hora que o sino toca, mas aqui não há sinos”. Aqui onde? Deixa-se essa pergunta em aberto por enquanto. Sublinha-se como 
após o emprego da conjunção adversativa, apresentam-se termos adjetivos encadeados, como se pode observar nos versos de dois a seis, principalmente, nos versos quatro e cinco, antes do estribilho "desta hora tenho medo".

O termo adversativo potencializa a força do argumento poético, haja vista que cria relação semântica antitética entre o anoitecer no campo com e o anoitecer na cidade, onde o sujeito poético está. E, para a comparação existir, duas vivências foram experimentadas. Há ritmos e sons diferentes para a existência campestre e para a existência citadina. Assim, misturando cenários, contrastam-se o barulho do sino que toca na igreja da vila campestre às seis da tarde com o ruído das buzinas, das sirenes, dos apitos que ecoam no fim de tarde da metrópole, local por excelência da modernidade.

Os adjetivos utilizados para qualificar as sirenes e os apitos, quais sejam, rouco, aflito, pungente, trágico qualifica $\mathrm{m}$ igualmente o homem da cidade moderna. No entanto, os ruídos estão "uivando" "escuros segredos". Escuros segredos de quê? Do caráter trágico e aflito da existência humana, na modernidade social, apartada da transcendência e mergulhada no materialismo e no pragmatismo?

No cenário citadino, a percepção parece adormecida e profundamente mecânica.
As buzinas, sirenes e apitos (metonímias para a cidade) esmagam o barulho do sino (metonímia da vila campestre). Ao serem sobrepostos, os termos referidos espremem a expressão "a hora em que o sino toca". Representa-se a sensação de compressão, pela quantidade de léxicos empregados para frisar um e outro espaço evocados, desta forma:

\section{APITOS AFLITOS, PUNGENTES, TRÁGICOS (CIDADE) SIRENES ROUCAS (CIDADE) \\ BUZINAS (CIDADE) \\ sino (campo)}

A aliteração do /s/ marca a estrofe inicial e alude ao ranger e aos ruídos da cidade. A assonância do /i/ pontua a intermitência e volta dos barulhos rítmicos característicos da metrópole com seus apitos. Qualificadores sonoros da cidade são estruturalmente recriados. Há, pois, concordância entre a forma e o conteúdo, entre o que se diz e o como se diz, conforme reconhece Hélcio Martins, em A rima na poesia de Carlos Drummond de Andrade:

Carlos Drummond de Andrade integra os melhores correspondentes do moderno pensamento estético, no sentido de que age poeticamente segundo o entendimento de que fenômenos como a rima estão a serviço da expressividade do poema, que ela só adquire esse valor de expressividade 
quando atua sobre o significante, estreitando-lhe o vínculo com o significado ou com a intenção criadora, e dessa maneira integrando-se no signo poético. (MARTINS, 1968, p. 133)

Estabelecida a relação adversativa nos seis primeiros versos, encontra-se a frase: "desta hora tenho medo". O verso funciona como estribilho, como refrão. O eu poético utiliza tal recurso expressivo como mecanismo para frisar e construir o encadeamento lógico do argumento poético ao longo das estrofes. Na obra $\mathrm{O}$ estudo analítico do poema, Antonio Candido (2006, p. 64) acentua a necessidade de se observar "a repetição de palavras, de frases e de versos, que se chama recorrência", pois a repetição faculta semânticas.

Em "Anoitecer", a recorrência acontece em três momentos: o primeiro verso das três primeiras estrofes começa com o verbo de ligação "é"; o segundo verso inicia com a adversativa "mas" e o último pela expressão "desta hora tenho medo". Veja-se a recorrência estrutural, na segunda estrofe do poema:

$8 E$ a hora em que o pássaro volta, 9 mas de há muito não há pássaros; 10 só multidões compactas

11 escorrendo exaustas
12 como espesso óleo

13 que impregna o lajedo;

14 desta hora tenho medo

O poema possui estrutura reiterativa e acumulativa. Repete-se a estrutura da primeira estrofe na segunda e na terceira estrofe. No segundo momento, sai o sino e entram os pássaros que cantam ao fim do dia. Assim que o substantivo e o predicativo aparecem no primeiro verso, a conjunção refuta a axiologia positiva na sequência. Todavia, diferentemente do primeiro verso, em que os ruídos do mundo moderno silenciam o sino, aqui o poeta cria símile, do décimo verso até o décimo terceiro, de força expressiva e semântica: "só multidões compactas/escorrendo exaustas/como espesso óleo / que impregna o lajedo".

Em "Anoitecer", a multidão aparece textualmente marcada. O espaço urbano surge, pois, tanto pela referência aos sons dessa, quanto a outros elementos característicos da metrópole, como, neste caso, a multidão. Assim, Carlos Drummond de Andrade pondera acerca de aspectos qualificadores do seu tempo. Alcides Villaça distingue a importância desse traço constitutivo do mundo moderno presente na lírica do poeta mineiro, bem como o uso desses aspectos (cidade, mercadorias, multidão) como mecanismos escolhidos por Carlos Drummond de Andrade para interrogar 
a modernidade, com suas grandes e pragmáticas máquinas de guerra, com sua engenharia de consumo, de publicidade e de massificação? Tal interrogação parece nascer, de fato, do próprio Drummond, e se impõe como ponto de partida mais do que problemático. Em outras palavras: há que se construir, sim, o símbolo poético, mas sem perder de vista a complexidade da matéria e a precariedade do sujeito, disposto a uma tarefa tão desafiadora para quem já se confessara um "gauche na vida".

A incisiva afirmação de um símbolo e as muitas ressalvas na sua produção de sentido são os termos do conflito dos melhores poemas de A rosa do povo. (VILLAÇA, 2006, p. 60)

$\mathrm{Na}$ cidade, saem as aves e entram as multidões. O pássaro simboliza a sabedoria, os estados espirituais e superiores do ser, bem como a alma individual de cada um, a força e a vida (CHEVALIER E GHEERBRANT, 2009). No entanto, não há pássaros na cidade, apenas "multidões compactas/ escorrendo exaustas/como espesso óleo/que impregna o lajedo”. Tal descrição cria a sensação de viscosidade e de gosma, como se a massa fosse uma lesma que rasteja e deixa asqueroso rastro. A sensação de viscosidade, assim como ocorre com os apitos e as sirenes da estrofe anterior, é reconstruída tanto imagética, quanto ritmicamente a través da assonância do /e/. Esse recurso expressivo cria a sensação de algo que escorrega, de pastosidade pela forma de articulação labial e sonora da vogal /e/.

A multidão equivale a uma espécie de "filha" da cidade moderna, portanto, "neta" do mundo moderno. Conforme discute Walter Benjamin (1989, p. 114), a multidão denota tema que "se impôs com maior autoridade aos literatos". Justificam-se as razões pelas quais a multidão a morfa funciona como temática cara à poesia moderna, assim como a excrescência das mercadorias. A sensação de solidão surge adjunta à imagem da multidão. Ou seja, avulta-se o afeto do homem ser mais um desconhecido na massa. Na nossa contemporaneidade, o excesso de exposição pessoal, principalmente, nas redes sociais funciona como tentativa de mascarar esse sentimento de insignificância.Unindo os pontos, cabe trazer o testemunho de Carlos Drummond de Andrade (2011, p. 181) sobre as "condições da vida moderna, que tem pressa e sugere pouco" marcadas pela multidão, pela solidão, pelo barulho e pelos formiga mentos diários:

A solidão é niilista. Penso numa solidão total e secreta de que a vida moderna parece guardar fórmula, pois para senti-la não é preciso fugir para Goiás ou as cavernas. No formigamento das grandes cidades, entre os roncos dos motores e o barulho dos pés e das vozes, o homem pode ser invadido bruscamente por uma terrível solidão, que o paralisa e 
o priva de qualquer sentimento de fraternidade ou temor. Um desligamento absoluto de todo compromisso liberta e ao mesmo tempo oprime a personalidade. Desta solidão está cheia a vida até hoje, e a instabilidade nervosa do nosso tempo poderá explicar o fenômeno de um ponto de vista científico; mas, poeticamente, qualquer explicação é desnecessária, tão sensível e paradoxalmente contagiosa é esta espécie de soledade. (ANDRADE, 2011, p. 28)

O homem comum, a vida banal, a rua, o trabalho, a fadiga e o repouso cabem na poesia de cada dia que nasce do olhar a tento do poeta. Aclaram-se, dessa forma, os elementos implícitos à "instabilidade nervosa do nosso tempo”. Nessa a rticulação, o sujeito poético canta um estar-no-mundo-caduco. Do apa rente olhar objetivo, afastado, descritivista e comparatista, uma perspectiva subjetiva emana pelo movimento oscilante entre o olhar do poeta e a cena citadina. Esta fere as retinas daquele e leva à reflexão supostamente apresentada de forma objetiva e direta. $\mathrm{Na}$ observação dos fatos corriqueiros de uma cidade e de sua multidão, nasce a dicção filosófica-existencial de alguns poemas drummondia nos, como acontece em "Anoitecer". O que poderia ser compreendido como a distanciada descrição do fim do dia ganha sentidos existenciais, questionadores, opressivos e desiludidos a ponto de o poeta ter medo da hora que tudo começa a escurecer. Se os pássaros e os sinos silenciaram, se tudo que parecia luz a noiteceu, então, o que esperar desse novo ciclo psicocultural pós-1945 em que tudo se apresenta como indefinição? O que surge após o crepúsculo da modernidade?

O eu poético observa o mundo, o que fomenta a argumentação erigida em poema e a possibilidade da poesia. A existência e o existente transformam-se em interrogação. Muitas das respostas obtidas são ocas de valores à proporção que a verdade se anuvia, o que está em concordância com o entendimento sobre a capacidade expressiva e o esta tuto da linguagem no mundo moderno - tema igualmente caro à lírica contemporânea.

Em Presenças reais: as artes do sentido, George Steiner (1989) distingue que a inquirição sobre a linguagem e seus limites representa, em nível profundo, ponderação de base teológica, de busca do sentido sobre o Sentido, em um plano físico cujos significados se turvaram. Complementando esse ponto de vista, em "Fazer, a poesia", Jean-Luc Nancy (2013, p. 419; grifos do autor) reconhece a poesia enquanto exigência de encontrar e articular $o$ sentido: "Ela [a poesia] não pronuncia, portanto, nada mais do que aquilo que faz o ofício da linguagem, a um só tempo sua estrutura e sua responsabilidade: articular sentido, entendendo-se que não há sentido senão numa articulação. Mas a poesia articula $o$ sentido, exatamente, absolutamente." Articular
EM TESE
BELO HORIZONTE
v. 25
N. 3
SET.-DEZ. 2019
DENUBILA. Entre subjetivo e citadino: "Anoitecer", de Carlos Drummond [...] P. 44-63 
algo representa identificar como partes diferentes se movimentam e geram movimento.

Mas exatamente pela dificuldade em se articular $o$ sentido que a metapoesia qualifica a lírica moderna. Os poetas a nalisa m o trabalho com a linguagem e, por sua vez, desnudam limites expressivos e sintáticos. De Manuel Bandeira a Má rio Quintana, entre tantos citáveis, escritores acentuam a dificuldade de se escrever poemas e de se identificar a poesia. Antonio Candido (2011) identifica a metalinguagem como traço qualificador da lírica do a utor de José, assim como de tantos outros poetas desde Baudelaire.

Em Coração partido: uma a nálise da poesia reflexiva de Drummond, Davi Arrigucci Jr. (2002) igualmente argumenta que, no processo de construção do sentido, algo constantemente barra o caminho do poeta. Nessa problemática de ordem aporética, há intensificação das interrogações que habitam a consciência do eu lírico. A constante dificuldade e a percepção de limites ressaltadas e identificadas para a construção do ato poético sublinham o obstáculo de se manejar a linguagem vernácula para, dessa forma, buscar $o$ sentido.

Em outros termos e retomando Carlos Drummond de Andrade, de "Procura da poesia", poetas verbalizam e explicita $m$ as pedras que marcam o caminho percorrido para transformar a língua em estado de dicionário em linguagem poética. Foge-se do ideário romântico de poeta inspirado. A produção de poemas com poesia exige capacidade contemplativa e esforço laboral para, assim, conseguir fazer com que um rompante de sentido apareça enquanto as coisas falam: "Poesia é fazer tudo falar" (NANCY, 2013, p. 421).

No caso de "Anoitecer", adotando lógica complementar e adversativa, as coisas falam e dão espaço a uma poesia interrogativa, reflexiva e densa. Até então, há no poema o som do campo esmagado pelos ritmos da cidade, assim como os pássa ros ausentes frente à multidão que ca minha viscosamente pela metrópole. Nesse percurso, outras questões surgiram, como a busca do sentido e a metapoesia.

$\mathrm{O}$ artefa to lírico reiteradamente demonstra que a hora que o eu poético sente medo é aquela descrita após o emprego da conjunção adversativa cujo valor se sobrepõe ao predicativo do sintagma nominal que inicia os versos. O momento citadino de passagem da luz do dia para as iniciais penumbras da noite fere a consciência lírica, bem como potencializa traços característicos do "formigamento das grandes cidades" pelo movimento da massa gosmenta. Em vista disso, o eu lírico nota como após mais um dia de trabalho, a multidão amorfa tem pressa para conseguir o descanso diário, conforme expresso na terceira estrofe. 
15 É a hora do descanso,

16 mas o descanso vem tarde,

17 o corpo não pede sono,

18 depois de tanto rodar;

19 pede paz - morte - mergulho

20 no poço mais ermo e quedo;

21 desta hora tenho medo.

Não negando o modus operandi estrutural do poema, a substância apresentada no primeiro verso da estrofe - o termo "descanso", no verso 15 - é refutado na sequência pela conjunção adversativa. O verbo "vir" e o substantivo "tarde" (com valor de advérbio, isto é, tardia mente) adicionam semânticas ao "descanso" - o descanso vem tardia mente, ou seja, não é uma questão temporal, um advérbio de tempo, mas sim de modo, o qual conota como algo acontece, aconteceu ou acontecerá. Segundo o Dicionário Houaiss, descanso consiste em um substantivo masculino que possui sete significados:

1. ato ou efeito de descansar; 2 repouso, folga; 3 período sem ocupação; vagar, ócio; 4 tranquilidade de espírito, sossego; 5 lentidão, morosidade Ex.: falar com d.; 6 utensílio que serve de suporte para objetos, tais como travessas de servir comida, copos, ferro de engomar etc; 7 espaço entre os lanços de uma escada; patamar. (HOUAISS, 2009, p. 632)

Entretanto, o valor desse termo chama outro caminho reflexivo não distinguido acima. A terceira estrofe se abre com referência a expressão eufemística utilizada para amenizar a notícia de morte, presente na fala corriqueira: "ele descansou”. O que os dois primeiros versos da terceira estrofe atenuam ganha dicção mais direta até chegarmos ao décimo nono verso, quando o uso de hifens enfatiza o termo "morte". Essa escolha estrutural pausa a leitura, pois o leitor lê ma is lenta mente o termo destacado no corpo da estrofe.Em função do constante movimento e agitação, a metrópole nega uma necessidade básica do corpo huma no, o descanso. Essa dinâmica do dia a dia aumenta ansiedades e temores, o que dificulta o descanso efetivo. Quando pondera acerca da lírica drummondiana e a reflexão sobre a cidade, Antonio Candido (2011, p. 78) identifica como "a sociedade oferece obstáculos que impedem a plenitude dos atos e dos sentimentos”. O indivíduo não pode parar, não pode descansar, pois a lógica produtivista o impede. Se ele parar outro não parou e pode tomar o seu lugar. $\mathrm{Na}$ multidão a morfa, ninguém é insubstituível. Cabe lembrar a clássica cena de Tempos Modernos, em que máquinas sugam Charles Chaplin, que passa a se movimentar de maneira 
contínua dentro delas, como se seu corpo e sua existência fossem apenas uma extensão do mecânico. O cenário que se desenhava como preocupante na década de 1940 ganha intensidade desde então a ponto de Byung Chul-Han (2017), em Sociedade do cansaço, pensar na era contemporânea não mais como a da depressão, mas sim como a da ansiedade. Exige tanto dos indivíduos que a saída desse círculo hermético parece ser a morte, único descanso possível.

Começa-se, neste momento, discretamente, a virada na axiologia do poema.

O eu poético sai das descrições de alguns dos elementos citadinos e chega aos efeitos emocionais e afetivos da cidade moderna. O desejo de aniquila mento se coaduna com a ausência de descanso ofertada pelo ritmo qualificador da cidade moderna. A cidade torna-se, portanto, elemento de revelação acerca das condições dos homens.

Em "Anoitecer", a cidade fala e ao falar revela aspectos da condição humana. O poeta mineiro "transforma o lugar-comum em revelação” (CANDIDO, 2011, p. 95). Revelação essa explicita na terceira estrofe, quando começa a ganhar corpo a meditação lírica sobre a morte, sobre a temporalidade do ser dos homens, outra das temáticas centrais da poética drummondiana, de acordo com Benedito Nunes:
Mediada pelo convívio com os mortos, e sempre contrabalançada pela atitude de resistência ética, que se fixa e nada espera dela, a experiência da morte, na poesia de Carlos Drummond, a partir de A Rosa do Povo, assimilará reflexivamente, através da experiência decepcionante do tempo e do amor, o próprio desejo de aniquilamento.(NUNES, 2009, p. 243).

No poeta mineiro, a ponderação sobre a morte acontece pela percepção da finitude e da deterioração do corpo individual, mais característica de uma poesia da velhice. $\mathrm{O}$ livro Corpo, de 1984, quando o eu poético descobre que "a a usência é um estar em mim” (ANDRADE, 2002, p. 1236) ilustra essa questão. Mas também acontece pela memória dos mortos, outro tema-chave do autor de Claro enigma.

Quando perscruta sobre a facticidade existencial, a consciência poética percebe que cada ser vivo carrega um a muleto invisível que o lembra tanto de sua condição existencial, qua nto de seus mortos. Amuleto como aquele que o sujeito lírico de "Tarde de Maio", exemplar elegia a morosa e fúnebre, de acordo com Samuel Titan Jr. (2012), traz em seu pescoço e que constantemente rememora ao eu poético da "tarde de maio, em que desaparecemos,/sem que ninguém, o amor inclusive, pusesse reparo" (DRUMMOND, 2002, p. 265). 
$\mathrm{Na}$ articulação entre finitude, lembrança e silêncio em que "há um abrir de baús/e de lembranças violentas" (DRUMMOND, 2002, p. 110), a temática da dissolução existencial se modela à medida que "a morte como matéria de experiências” (NUNES, 2009, p. 243) aparece em "Anoitecer". Nessa trajetória epistêmica, a ponderação sobre a morte se aproxima da do tempo e da memória, pois a consciência lírica percebe

o tempo irreversível e ambíguo, única medida absoluta para o mundo puramente humano de Drummond. Destruindo e conservando, doando e subtraindo, o tempo nos concede no presente, como ganho da memória, aquilo que retirou e exauriu da vida no passado. E se apenas doa com o que subtrai de nós, o fluxo da duração interior, garantia de nossa continuidade, desgasta-nos ao conservar-nos: "Tudo foi prêmio do tempo/e no tempo se converte". (NUNES, 2009, p. 249)

A memória equivale à filha do tempo. Como demonstra Benedito Nunes (2009), o tempo representa força destrutiva intensa que apenas em raríssimos momentos pode ser vencido. Isso se dá por intermédio da memória involuntária, como apresenta Marcel Proust, em seu ciclo de romances que compõem Em busca do tempo perdido, do qual Drummond é um dos tradutores, assim como Mário Quintana. Tal ideia equivale à possibilidade de anular o avanço temporal por alguns segundos, qua ndo o sujeito encontra inesperadamente pedaços da sua existência espalhados em objetos esquecidos.

O processo é similar ao que acontece com o eu poético de "Tarde de Maio", que deixou porção de sua alma espalhadas no "solo ardente" (ANDRADE, 2002, p. 264). No caso proustiano, o narrador reencontra o tempo perdido da infância ao beber chá de tília e comer bolinho madeleine. Por outro lado, existe a memória voluntária, menos forte que a involuntária, de acordo com a ótica proustiana. Na rememoração, tanto a forçada, qua nto a inesperada, há possibilidade de sobrevida aos mortos e de momentos pretéritos. Contudo, nessa vivência, o lembrete que o mesmo destino espera aquele que carrega o amuleto em vida hoje.

Os passos dados a té então demonstram como "Anoitecer" nasce do choque com realidades e constatações de ordens diversas. Há o apontamento de mecanismos sociais e, em alguns casos, o sentimento de compromisso com a desalienação daqueles que não enxergam as engrenagens da sociedade moderna. Todavia, existe também a ponderação de ordem existencial. Ambas causam a densidade semântica do poema em apreço. Aquilo que parecia social se torna 
existencial à medida que a inquirição ontológica responsável pela confissão lírica se configura na terceira estrofe e ganha maior delimitação na quarta e última:

21 Hora de delicadeza,

22 gasalho, sombra, silêncio.

23 Haverá disso no mundo?

24 É antes a hora dos corvos,

25 bicando em mim, meu passado,

26 meu futuro, meu degredo;

27 desta hora, sim, tenho medo.

A última estrofe se apresenta modificada estruturalmente em relação às três anteriores. Não se opera o movimento de afirmação e de negação. Não há o verbo de ligação iniciando o primeiro verso e a conjunção adversativa refutando o predicativo do sujeito no segundo. Em vez da negação, eu lírico interroga a si, no terceiro verso da última estrofe. Mas ta mbém apresenta uma inquirição ao leitor e, assim chama a participação deste. A pergunta joga o argumento poético de "Anoitecer" para o leitor e faz com que esse se pergunte: "Haverá disso no mundo?". Formulando de outra maneira: Haverá delicadeza, gasalho, sombra, silêncio na cidade moderna ou há apenas buzinas, sirenes roucas, apitos aflitos, pungentes, trágicos, multidões compactas que escorrem como espesso óleo que impregna o lajedo?

Com esse caminho semântico, o sujeito lírico oferece a percepção lírica não através da voz poética como autoridade, mas sim por meio de observação e de interrogação. Não afirma que é assim, mas quer que o leitor constate que funciona assim. A dinâmica retórica a rquitetada exige, pois, ponderação e participação. Entre pergunta e respostas, o vislumbre do funcionamento da "máquina do mundo" contemporânea, bem como o movimento de interioridade-exterioridade. Com essa escolha, se entrevê o lado participativo valorizado pelo a utor mineiro. A percepção do poeta contemplando o externo faculta apreensões expressas em poemas. O leitor internaliza a visão apresentada e pode ver, de maneira diferente, o externo e sua práxis. Tal dinâmica revela como "todo poema cuja matéria fluida e permanente não se confirma no olhar do outro a meaça reduzir-se, de fato, ao 'simples papel' de uma folha sem marcas, da matéria neutra e irrelevante de uma página perdida" (VILLAÇA, 2006, p. 72).

A interrogação funciona como instrumento para chamar ao outro e fazer com que $o$ sentido aconteça como articulação entre as coisas que falam e geram a poesia, mas também como articulação entre perspectivas. Eis uma maneira de 
estabelecer o sentido. Ao "fazer, a poesia", retomando o título do ensaio de Jean-Luc Nancy (2013),

o eu poético executou sua parte ao construir um poema com valor literá rio e com poesia. Ou seja, ele fez a poesia e ao fazê-la atingiu o limitar aonde poderia ir. Agora cabe aos leitores continuarem.

O que é fazer? É dispor no ser. O fazer exaure-se tanto na disposição como em seu fim. Esse fim que ele estabeleceu como meta, eis que ele é tanto seu fim quanto sua negação, pois o fazer se desfaz em sua perfeição. Mas o que é desfeito é identicamente o que é disposto, perfeito e mais que perfeito. O fazer acaba, a cada vez, alguma coisa e a si mesmo. Seu fim é sua finição: nisso, ele se dispõe infinito, a cada vez infinitamente mais além de sua obra.

O poema é a coisa feita do próprio fazer. (NANCY, 2013 p. 420)

Enqua nto faz, o poeta vence o limite comunicativo e o embate com as palavras em estado de dicionário, elevadas agora à condição de signos poéticos. Existe, portanto, elemento dotado de força comunicativa à medida que aliterações, assonâncias, ritmos, imagens e argumentos se conectam e significa m. Ou seja, forma e conteúdo estão em harmonia e comunicam, já que comunicar não significa ter algo a dizer, mas sim a capacidade de estabelecer relações. Pa ra isso acontecer, torna-se imprescindível a sintaxe poética privilegiada de autores como Carlos Drummond de Andrade.

\section{TERCEIROS PASSOS}

Após o eu lírico descrever aspectos sociais e afetivos caros ao ambiente urbano e jogar ao leitor a complementariedade semântica com a interrogação apresentada no vigésimo terceiro verso, a persona poética marca, nos versos finais, a subjetividade latente e inerente à construção da peça lírica. Há, pois, caminho ascendente na manifestação subjetiva que abre caminhos interpreta tivos. O lirismo inicialmente tímido identificado no estribilho pelo sujeito oculto "eu" da expressão "tenho medo" - "desta hora [eu] tenho medo" - caminha para a confissão lírica. Primeiro, o tom pessoal praticamente ausente nas duas primeiras estrofes. Depois, a coletividade expressa na pergunta retórica. Por fim, o caráter íntimo, o lírico em sua ma nifestação direta, toma corpo do vigésimo quinto verso em diante com o uso de pronomes possessivos e de pronome oblíquo tônico.

A mudança estrutural operada, na quarta estrofe, dá espaço à confissão lírica discreta até então e que se se adensa a partir do vigésimo quarto verso. Nele o verbo de ligação "é", que abre os outros três andamentos, aparece no meio 
da estrofe para descrever uma condição; condição essa não refutada pelo uso da conjunção adversativa, e sim pela proeminência da certeza. A cadência semântica se transforma. No lugar da partícula que cria sentido adversa tivo, a presença de elemento de valor afirmativo. Sai o "mas" e entra o "sim". Apesar da descrição da realidade social e o subsequente tom de desanuviar da condição coletiva característica do mundo moderno, aspecto qualificador de parte dos poemas de A rosa do povo e de "Anoitecer", o advérbio de afirmação ratifica a mudança de tom ao explicitar o medo do eu lírico, qual seja, o da finitude, o das incertezas da morte. Avulta-se o receio de que o poeta sente do anoitecer em outra perspectiva. Não mais do dia na cidade grande, mas sim o anoitecer da existência e os posteriores mistérios. Anoitecer inicialmente usado para delimitar a hora do dia e depois para assinalar o a noitecer da facticidade do existir A proposição final adensa o sentindo do título do poema o que contribui, pois, para o aspecto dicotômico erguido.

Os versos finais trazem a reflexão sobre a morte, vista como passagem do conhecido ao desconhecido após a conclusão do ciclo existencial, fazendo referência à simbologia do número sete. Da observação da realidade prosaica, corriqueira e urbana, o eu poético drummondia no a umenta o ângulo argumentativo e chega à reflexão de caráter existencial. Dois contextos epistêmicos marcam "Anoitecer".
Visão crítica e confissão lírica, em peso e contrapeso, dão ao poema a carga expressiva que se constrói tanto pelos aspectos expressivos formais, quanto pelos aspectos expressivos existenciais.

Elementos empíricos formam o mundo material, como as buzinas, os ruídos, as cidades, as multidões, mas há ta mbém um mundo interno, isto é, a subjetividade e a temporalidade dos homens representadas pelo medo da morte. Nesse medo, o caráter inevitável e trágico do "sim" textualmente demarcado, no último verso. Sim que, mais hora, menos hora, chega a tudo e todos que factualmente existem. Assim como o dia amanhece e anoitece, a existência ta mbém, sendo que são desses momentos certeiros fina is que o eu lírico de "Anoitecer" se amedronta, quando tudo se torna escuridão e incerteza. Todavia, esse receio final, essa sentença derradeira não a nula o caráter questionador e analítico das estrofes anteriores.

O poema se constrói pelo movimento entre afirmação e rápida negação. Esta faz com que o predicativo do sujeito mal tenha tempo de se desenvolver. No entanto, "Anoitecer" finaliza com uma afirmação responsável por demonstrar que, no jogo de ambivalências e de dúvidas qualificadoras da existência humana, temos apenas a certeza do inevitável fim. Entre axiologias adversativas e predicativas 
estruturalmente marcadas no artefato lírico, um sim final é certo. Esse medo do desconhecido lembra aos leitores de "Anoitecer" que, apesar de toda a objetividade e a dinâmica exigidas pela cidade moderna, aqueles que a fazem movimentar não são tão dinâmicos e objetivos a ponto de vencer o próprio passar do tempo. Após o derradeiro sim subjetivo e coletivo, que une os caminhos do existente, os indivíduos serão memória/tempo e depois provavelmente nada. Eis a razão de o poeta utilizar o termo degredo para demarcar a expulsão e o afasta mento da terra, a morte como o degredo da matéria e da ação da temporalidade.Independentemente da crítica à exterioridade e à realidade da cidade moderna, o poema se fecha explicitando a subjetividade do eu lírico, o seu medo da morte, dos "corvos bicando" o "passado". Este representado pelas memórias e pelos mortos que habitam a poesia drummondiana, como o silencioso pai que anda com o eu poético, conforme acontece em "Viagem na família”. Mas os corvos ta mbém bicam o presente à medida que sujeito lírico acumula, em cada segundo, as cinzas da hora, retomando Manuel Bandeira, outro poeta de grande envergadura e que semelhantemente refletiu sobre a morte. Os corvos bicam ta mbém o futuro. A simbólica projetação temporal demarca que o eu poético tem ciência de que se tornará memória após a morte e sem os vivos cai no nada da indefinição, da incerteza e do esquecimento.Chegada a hora do fim do corpo físico, o sujeito ainda pode existir como reminiscência naqueles que factualmente existem Mesmo findada a existência terrena, os corvos-tempo continuam a bicar os que não mais existem, uma vez que os mortos (re)vivem por intermédio da memória dos que existem e esses sofrem as bicadas dos corvos-tempo no presente. Após eles acabaram com a matéria bicada no passado, no presente e no futuro, pode acontecer o momento que não restará nem mais a lembrança da existência do que já foi e, assim, o referido abismo do indefinido em final degredo. A existência acaba como matéria e como memória. É dessa hora, quando o ser se torna profundamente nada que o eu poético sim tem medo.

Apesar das diferenças sociais inerentes ao modo como a sociedade moderna se construiu, no fim das contas, cabe a todos que compõem a a morfa multidão o mesmo e inevitável fim delimitado pelo advérbio de afirmação no último verso, assim como cabe a todos a possibilidade ou não de continuar existindo como memória nos vivos após a morte. Nesse sentido, lembra-se o título da obra Verso universo em Drummond, de José Guilherme Merquior (2011), visto que um "simples" sim em curto verso foi capaz de chamar a um universo; universo esse no sentido de a mplidão, de abrangência reflexiva e também de segredos e de limites cognoscíveis. 
No poema em apreço, a cidade com seus elementos fala e produz semânticas, mas ta mbém o sujeito lírico fala e igualmente produz significações. Essa articulação embebe o poema de poesia. Poesia, no caso de "Anoitecer", ao mesmo tempo social e existencial, o que sublinha a força poética drummondiana. Como exposto, Jean-Luc Nancy (2013) acredita que o sentido acontece em processo de articulação Ou seja, cada parte possui independência, mas o conjunto se movimenta e funciona se essas independências trabalharem em relação. Isso acontece no poema lido, em que o como e $o$ $q u \hat{e}$ se articulam e se comunicam. Por esse motivo, Carlos Drummond de Andrade (2011, p. 59) cria um objeto lírico rico à medida que "se alimenta" da temporalidade coletiva e subjetiva.

\section{REFERÊNCIAS}

ADORNO, T. Palestra sobre lírica e sociedade. Tradução de Jorge M. B. de Almeida. In Notas de literatura I.

São Paulo: Editora 34, 2003. pp. 65-89.

ANDRADE, C. D. de. Confissões de Minas. São Paulo: Cosac Naify, 2011

Poesia completa. Introdução de Silviano Santiago Rio de Janeiro: Nova Aguilar, 2002.
Prosa seleta. Rio de Janeiro: Nova Aguilar, 2003

ARRIGUCCI JR., D. Coração partido: uma análise da poesia reflexiva de Drummond. São Paulo: Cosac Naify, 2002.

BAUMAN, Z. Modernidade e holocausto. Tradução de

Marcus Penchel. Rio de Janeiro: Jorge Zahar, 1998.

BENJAMIN, W. Obras Escolhidas III: Charles Baudelaire um lírico no auge do capitalismo. Tradução de José Martins Barbosa e Hemerson Alves Baptista. São Paulo: Brasiliense, 1989

CANDIDO, A. Inquietudes na poesia de Drummond. In:

Vários Escritos. 5. ed. Rio de Janeiro: Ouro Sobre o Azul, 2011. p. 69-99.

O estudo analítico do poema. 5. ed. São Paulo: Humanitas, 2006.

CHEVALIER, J.; GHEEBRANT, A. Dicionário de símbolos. Tradução de Vera da Costa e Silva. 23. ed. Rio de Janeiro: José Olympio, 2009 
HAN, Byung-Chul. Sociedade do cansaço. 2. ed. Tradução de Enio Paulo Giachini. Petrópolis, Vozes, 2017.

HOUAISS, A. Dicionário Houaiss da Língua Portuguesa. Rio de Janeiro: Objetiva, 2009

LAFETÁ, João Luís. 1930: a crítica e o Modernismo. 2. ed. São Paulo: Ed. 34/USP, 2000

MARTINS, Hélcio. A rima na poesia de Carlos Drummond de Andrade. Rio de Janeiro: José Olympio, 1968.

MERQUIOR, José Guilherme. Verso universo em

Drummond. São Paulo: É realizações, 2011.

NANCY, Jean-Luc. Fazer, a poesia. Tradução de Letícia Della Giacoma de França, Janaina Ravagnono e Maurício Mendonça Cardozo. Alea, Rio de Janeiro, v. 15/2, p. 414 422, jul-dez 2013.

NUNES, B. A clave do poético. São Paulo: Companhia das Letras, 2009.
SANTIAGO, S. Introdução a leitura dos poemas de Carlos Drummond de Andrade. In: ANDRADE, C. D. de. Poesia completa. Rio de Janeiro: Nova Aguilar, 2002. p. III-XLI.

STEINER, G. Presenças reais: as artes do sentido. Tradução de Miguel Serras Pereira: Lisboa: Presença, 1989.

TITAN JR., S. Um poeta do mundo terreno. In ANDRADE, C. D. de. Claro Enigma. São Paulo: Companhia das Letras, 2012

VILAÇA, A. Passos de Drummond. São Paulo: Cosac Naify, 2006

Recebido em: 26-08-2019 Aceito em: 07-01-2020 